\title{
Doxorubicin-Induced Cardio Toxicity in Albino Rats Protected by Adansonia Digitata (Baobab) Leaf Extract
}

\begin{abstract}
Akintola Adebola Olayemi $^{1^{*}}$, Kehinde Busuyi David ${ }^{2}$, Saka Waheed Adeoye ${ }^{3}$, Oyewande Esther Ajoke ${ }^{1}$, Ayandiran Tolulope Akinpelu ${ }^{4}$ and Ogundiran Mathew Akinloye ${ }^{4}$

${ }^{1}$ Department of Science Laboratory Technology, Faculty of Pure and Applied Sciences, Ladoke Akintola University of Technology, P.M.B-4000, Ogbomoso, Nigeria.

${ }^{2}$ Department of Biochemistry, Faculty of Basic Medical Sciences, Ladoke Akintola University of Technology, P.M.B-4000, Ogbomoso, Nigeria.

${ }^{3}$ Department of Physiology, Faculty of Basic Medical Sciences, Ladoke Akintola University of Technology, P.M.B-4000, Ogbomoso, Nigeria.

${ }^{4}$ Department of Pure and Applied Biology, Faculty of Pure and Applied Sciences, Ladoke Akintola University of Technology, P.M.B-4000, Ogbomoso, Nigeria.
\end{abstract}

Authors' contributions

This work was carried out in collaboration among all authors. Authors KBD, AAO conception of research of this manuscript. Author SWA writing of manuscript; all authors works research and funding of this manuscript. Author KBD analysis of research this manuscript. All authors read and approved the final manuscript.

Article Information

DOI: $10.9734 / A R R B / 2021 / v 36 i 730395$ Editor(s):

(1) Dr. Bechan Sharma, University of Allahabad, India.

Reviewers:

(1) Eylem Taskin, Nigde Omer Halisdemir University, Turkey. (2) Heba Gamal Abd El-Aziz Nasr, Al-Azhar University, Egypt. Complete Peer review History: https://www.sdiarticle4.com/review-history/69342

Original Research Article

Received 02 April 2021 Accepted 09 June 2021 Published 13 July 2021

ABSTRACT

Cardiovascular disease is the world's leading cause of death, killing 17 to 19 million people each year. The usage of traditional drugs was influenced by the need for effective medications for the treatment of cardiovascular disease without side effects. The current study investigated the cardioprotective effects of Adansonia digitata leaf extract on doxorubicin-mediated cardiotoxicity in 
laboratory rats. Thirty-five albino rats were divided into five groups, each consisting of seven rats. Group 1 was given filtered water as a control, while Group 2 was given saline and doxorubicin, Group 3 received doxorubicin and Vitamin E, and Groups IV and V were myocardial oxidative animals treated with Adansonia digitata leaf extract (150 and $300 \mathrm{mg} / \mathrm{kg} / \mathrm{wt}$ ) for two weeks. After the rats were sacrificed, their hearts were collected and homogenized for biochemical assays. The results on the activities of creatinine kinase (CK), lactate dehydrogenase (LDH), aspartate amino transferase (AST), nitric oxide synthase (NOS), superoxide dismutase (SOD), catalase (CAT), and malondialdehyde were determined. Histopathology examination was used in addition to assays to validate myocardial damage. In comparison to the control group, rats provided doxorubicin showed a significant increase in the activities of cardiac marker enzymes (CK, LDH, and AST), as well as a significant increase in malondialdehyde concentration with a concomitant decrease in antioxidant enzymes (SOD, CAT, and NOS), implying cardiotoxicity. In rats with doxorubicin-induced myocardial infection, pretreatment with Adansonia digitata leaf extract reduced myocardial damage, these biochemical results were confirmed by histopathology. Finally, the new study demonstrates that Adansonia digitata has cardioprotective properties.

Keywords: Cardiovascular disease; Adansonia digitata; doxorubicin; cardiotoxicity; leaf extract.

\section{INTRODUCTION}

Acute lymphocytic leukemia, breast cancer, bladder cancer, kaposi sarcoma, lymphoma, and lymphoma are also treated with doxorubicin (DOX) [1]. It belongs to the anthracyline antibiotic family which functions by interacting with DNA activity. This medication's side effects include baldness, marrow suppression, weakness, itch, and mouth inflammation. Possible adverse effects include allergic reactions such as anaphylaxis, as well as heart injuries. Dilated cardiomyopathy, or cardiac failure, is the most serious doxorubicin side effect. Dilated cardiomyopathy is caused by doxorubicininduced cardiomyopathy, which causes all four heart chambers to swell [2]. This causes systolic and diastolic instability, as well as cardiac disease, which has a $50 \%$ mortality rate $[3,4,2]$. As a result of the adverse effects of commercially approved synthetic cardioprotective medicines. The cardioprotective properties of certain protected medicinal plants have been investigated. [5,6,7]. Adansonia digitata, also known as Baobab, is the Adansonia family's most commonly spread tree species and is native to Africa [8]. Baobab is a multipurpose tree that produces berries, clothing, medication, and raw materials for a range of items. The baobab fruit pulp, nuts, bulbs, stems, and bark are all edible $[9,10,11,12,13]$. Vitamin $C$, calcium, phosphorus, carbohydrates, fibers, potassium, protein, and lipids are all found in abundance in this fruit $[14,15,16,12,17]$. Malaria, tuberculosis, fever, microbial infection, diarrhea, anemia, dysentery, toothache, inflammation, and asthma are only a few of the illnesses that the plant's various sections are used to handle
$[18,19,20,21,22,12,23]$. Adansonia digitata fruit offered cardiioprotective effect from isoproterenol-induced myocardial damage [17]. There is, however, no scientific evidence that Adansonia digitata leaf has cardioprotective properties. As a result, the aim of this study was to investigate whether a methanolic extract of Adansonia digitata leaf affected cardiac marker enzymes and oxidative stress markers in rats suffering from doxorubicin-induced myocardial infarction.

\section{MATERIALS AND METHODS}

\subsection{Plant Materials and Preparation of Methanolic Extract}

Fresh leaves of Adansonia digitata (Voucher no: LHO 544) were collected from the Ladoke Akintola University of Technology Staff School Area, Ogbomoso, Oyo State, Nigeria, and classified and checked at Botany Section of the Department of Pure and Applied Biology. Ogbomoso. The plant leaves were air dried, powdered, measured, and soaked in cold methanol for 5 days before being condensed in a rotary evaporator and permitted to evaporate at room temperature to produce the semi-solid material known as the Adansonia digitata methanolic extract.(ADME).

\subsection{Chemicals and Drugs}

The majority of the chemical materials utilized during the study came from Sigma Chemicals Co. (St Louis, Mo, USA). Doxorubicin was provided by Pfizer Global Pharmaceutical Limited in Nigeria. All kits used were Agappe Diagnostics Switzerland $\mathrm{GmbH}$. 


\subsection{Experimental Animals}

Mature male Laboratory rats whose weight range between, $200 \mathrm{~g}$ to $250 \mathrm{~g}$ were obtained from Ladoke Akintola University of Technology, Anatomy Department's animal house. The animals were housed in ventilated plastic cages with free access to water and a standard pellet diet.

\subsubsection{Design of experiment}

The rats (35 in total) were divided into five groups, each with seven animals. Group 1 was provided purified water as a control, while Group II received regular saline and DOX (85 mg/kg/wt) intraperitoneally, Group III received vitamin E (150 $\mathrm{mg} / \mathrm{kg} / \mathrm{wt})$ and DOX (85 mg/kg/wt) intraperitoneally, Group IV received 150 $\mathrm{mg} / \mathrm{kg} / \mathrm{wt}$ of the extract and DOX (85 mg/kg/wt) intraperitoneally, and Group V received 300 $\mathrm{mg} / \mathrm{kg} / \mathrm{wt}$ of the extract The extract was provided for twenty-eight days, followed by five days of doxorubicin treatment.

\subsubsection{Blood collection and heart homogenate preparation}

Cervical dislocation was used to sacrifice rats from both groups. To collect plasma for biochemical assays, blood was obtained from the heart into well-labeled heparinised bottles and centrifuged at 4,000 rpm for 5 minutes. The heart was quickly removed and rinsed in 1.15 percent $\mathrm{KCl}$ before being dried, weighed, and homogenized in a chilled $10 \mathrm{mM}$ Tris/ $\mathrm{HCl}$ buffer $\mathrm{pH} 7.4$ and $0.25 \mathrm{M}$ sucrose solution. To obtain the supernatant for biochemical assays, the homogenate was centrifuged at 12,000 rpm for 60 minutes.

\subsection{Biochemical Analysis}

\subsubsection{Cardiac biochemical marker assessment}

Wurzburg et al. [24] and Szasz et al. [25] methods were used to determine the activity of creatinine kinase (CK). The activity of lactate dehydrogenase (LDH) was determined using the Witt and Trendelenburg method. The cardiac aspartate amino transferase (AST) activity was measured using the colorimetric system of Reitman and Frankel [26], as defined by Ochei and Kolhatkar[27].

\subsubsection{Cardiac antioxidant markers assessment}

The activity of superoxide dismutase (SOD) in the heart was measured using Misra and
Fridovich's [28] method, which was later modified by Kakkaret al. The activity of catalase was determined using the Aebi method [29]. The activity of nitric oxide synthase (NOS) was determined using the Marcocciet al. [30] method. The level of lipid peroxidation as malondialdehyde (MDA) was determined using the Varshneyand Kale principle [31].

\subsection{Histological Analyses}

The hearts were removed and immediately rinsed in saline before being fixed in $10 \%$ buffered formalin. The hearts were embedded in paraffin, sectioned at $5 \mu \mathrm{m}$, and stained with haematoxylin and eosin after being stored in $10 \%$ buffered formalin. The histological changes in these sections were examined under a light microscope.

\section{RESULTS}

\subsection{Assessment of Cardiac Biochemical Markers}

Table 1 summarizes the effects of doxorubicin and Adansonia digitata methanolic extract on cardiac marker enzyme activities (CK, LDH, and AST). Doxorubicin caused significant myocardial damage, resulting in a significant $(P<0.05)$ increase in cardiac LDH, CK and AST activities in pathogenic rats (Group II) when compared to the control rats (Group 1), whereas methanolic leaf extract (Group IV and Group V) and Vitamin E treatment (Group III) significantly decreased the elevated activities of cardiac CK, LDH, and AST, as shown in Fig. 1.

\subsection{Assessment of Cardiac Antioxidant and Oxidative Stress Markers}

When comparing the pathogenic group (Group II) to the control group (Group 1) rats, the activities of myocardial endogenous antioxidant markers (NOS, CAT, SOD) and oxidative stress marker (MDA) were significantly reduced $(P<0.05)$, but these reductions were significantly reversed in Groups III, IV, and V rats (Table 2 and Fig. 2). Pretreatment with a Adansonia digitata methanolic extract and Vitamin $E$ significantly reduced the elevated level of malondialdehyde in Group IV, Group V and Group III respectively compared to the untreated Group I. (Table 2 and Fig. 2). 
Table 1. The effect of methanolic extract of Adansonia digitata on creatinine kinase, lactate dehydrogenase and aspartate aminotransferase activities in doxorubicin-induced myocardial injury in rats

\begin{tabular}{|c|c|c|c|c|c|}
\hline PARAMETERS & $\begin{array}{l}\text { GROUP I } \\
\text { (Normal saline) }\end{array}$ & $\begin{array}{l}\text { GROUP II } \\
\text { (DOX-induced untreated) }\end{array}$ & $\begin{array}{l}\text { GROUP III } \\
\text { (DOX-induced + Vit. E }\end{array}$ & $\begin{array}{l}\text { GROUP IV } \\
\text { (DOX-induced + } 150 \\
\text { mg/kg/wt ADME) }\end{array}$ & $\begin{array}{l}\text { GROUP V } \\
\text { (DOX-induced + } 300 \\
\text { mg/kg/wt ADME) }\end{array}$ \\
\hline $\begin{array}{l}\text { CK }(U / L) \\
\text { LDH (U/L) } \\
\text { AST }(U / L)\end{array}$ & $\begin{array}{l}15.40 \pm 1.97^{a} \\
212.13 \pm 0.91 \\
24.78 \pm 0.71^{a}\end{array}$ & $\begin{array}{l}51.63 \pm 0.75 \\
317.73 \pm 1.50 \\
58.73 \pm 0.97\end{array}$ & $\begin{array}{l}21.65 \pm 1.60^{a} \\
254.63 \pm 1.68^{a} \\
27.38 \pm 0.57\end{array}$ & $\begin{array}{l}22.64 \pm 0.97^{\mathrm{a}} \\
278.50 \pm 0.21^{\mathrm{a}} \\
40.98 \pm 1.81^{\mathrm{abc}}\end{array}$ & $\begin{array}{l}21.68 \pm 1.99^{\mathrm{a}} \\
264.58 \pm 1.3^{\mathrm{a}} \\
37.48 \pm 1.18^{\mathrm{abc}}\end{array}$ \\
\hline
\end{tabular}

The values are represented as mean SEM, with $n=7$ rats and were reported significant at $(P<0.05)^{a}$ Symbolize a significant change in comparison with $D O X,{ }^{b}$ Symbolize a significant change in comparison with normal saline, ${ }^{c}$ Symbolize a significant change in comparison with DOX + Vit E, $D O X=$ Doxorubicin; $A D M E=$ Adansonia digitata methanolic extract

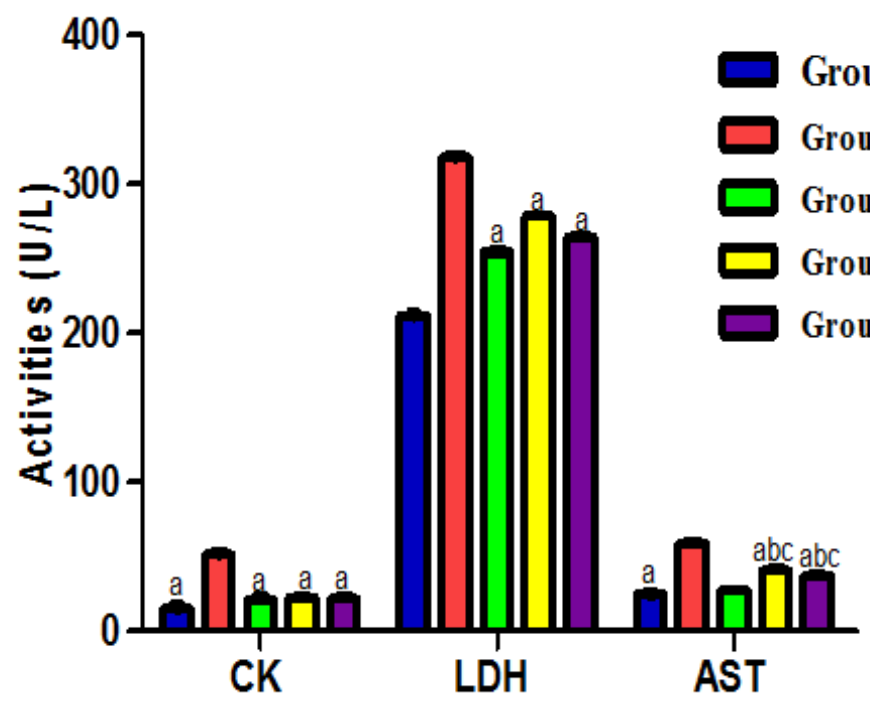

Fig. 1. Effects of methanolic leaf extract of Adansonia digita on creatinine kinase, lactate dehydrogenase and aspartate amino transferase activities in doxorubicin-induced injury in male rats 
Table 2. The Effect of methanolic leaf extract of Adansonia digitata on nitric oxide synthase, catalase, superoxide dismutase activities and malondialdehyde concentration in doxorubicin induced myocardial injury in rats

\begin{tabular}{|c|c|c|c|c|c|}
\hline PARAMETERS & $\begin{array}{l}\text { GROUP I } \\
\text { (Normal saline) }\end{array}$ & $\begin{array}{l}\text { GROUP II } \\
\text { (DOX-induced untreated) }\end{array}$ & $\begin{array}{l}\text { GROUP III } \\
\text { (DOX-induced + Vit. E }\end{array}$ & $\begin{array}{l}\text { GROUP IV } \\
\text { (DOX-induced + } 150 \\
\text { mg/kg/wt ADME) }\end{array}$ & $\begin{array}{l}\text { GROUP V } \\
\text { (DOX-induced + } 300 \\
\text { mg/kg/wt ADME) }\end{array}$ \\
\hline $\mathrm{NOS}(\mu \mathrm{mol} / \mathrm{gtissue})$ & $28.10 \pm 1.53^{\mathrm{a}}$ & $15.10 \pm 0.98$ & $26.40 \pm 1.04^{\mathrm{a}}$ & $20.55 \pm 1.86$ & $22.65 \pm 0.79$ \\
\hline CAT( $\mu \mathrm{mol} / \mathrm{gtissue})$ & $23.68 \pm 1.91$ & $7.36 \pm 0.73$ & $14.53 \pm 1.34^{\mathrm{a}, \mathrm{b}}$ & $16.25 \pm 0.28^{\mathrm{a}, \mathrm{b}}$ & $15.90 \pm 0.90^{\mathrm{a}, \mathrm{b}}$ \\
\hline $\mathrm{SOD}(\mu \mathrm{mol} / \mathrm{gtissue})$ & $29.93 \pm 1.09^{a}$ & $13.40 \pm 0.91$ & $23.13 \pm 0.63^{a, b}$ & $17.73 \pm 1.74^{\mathrm{b}, \mathrm{c}}$ & $22.75 \pm 0.89^{\mathrm{a}, \mathrm{b}}$ \\
\hline MDA(nmol/gtissue & $9.52 \pm 0.42^{a}$ & $28.05 \pm 1.21$ & $11.22 \pm 1.59^{a}$ & $11.98 \pm 0.49^{\mathrm{a}}$ & $11.65 \pm 0.70^{\mathrm{a}}$ \\
\hline
\end{tabular}

significant change in comparison with normal saline, ${ }^{C}$ Symbolize a significant change in comparison with DOX + Vit $E ; D O X=D o x o r u b i c i n, A D M E=A d a n s o n i a$ digitata methanolic extract

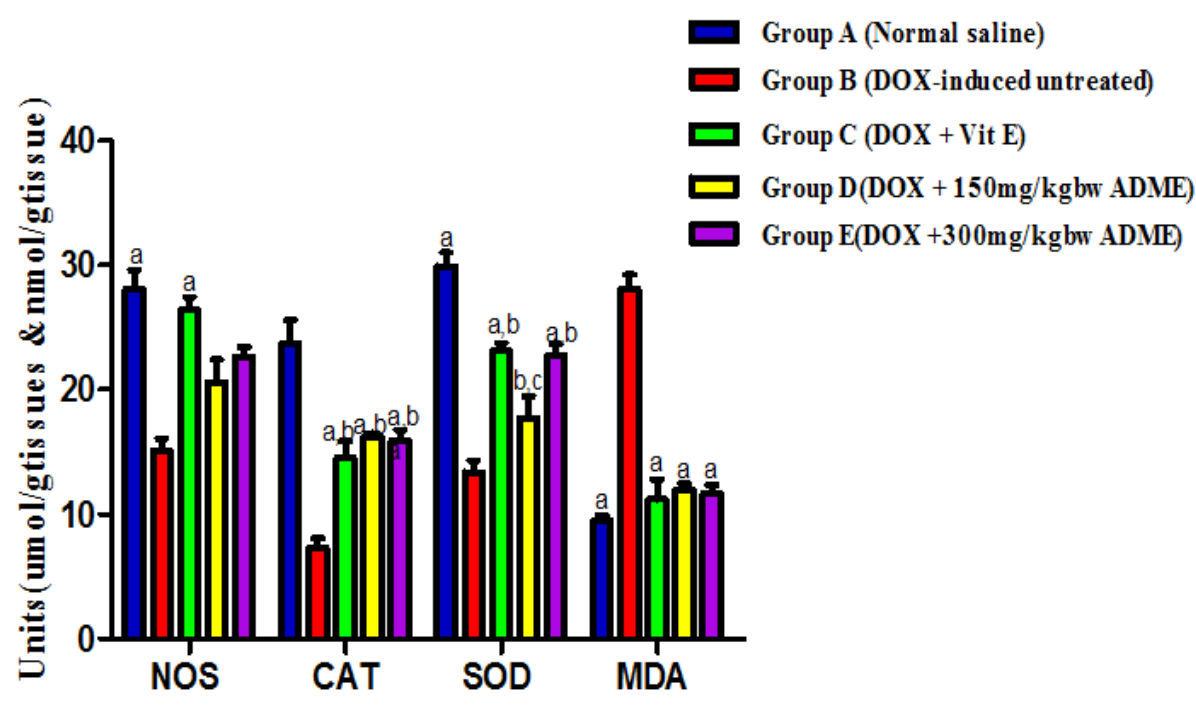

Fig. 2. Effects of methanolic leaf extract of Adansonia digita on catalase, superoxide dismutase, nitric oxide synthase activities and malondialdehyde concentration in doxorubicin-induced injury in male rats 


\subsection{Histopathology Study}
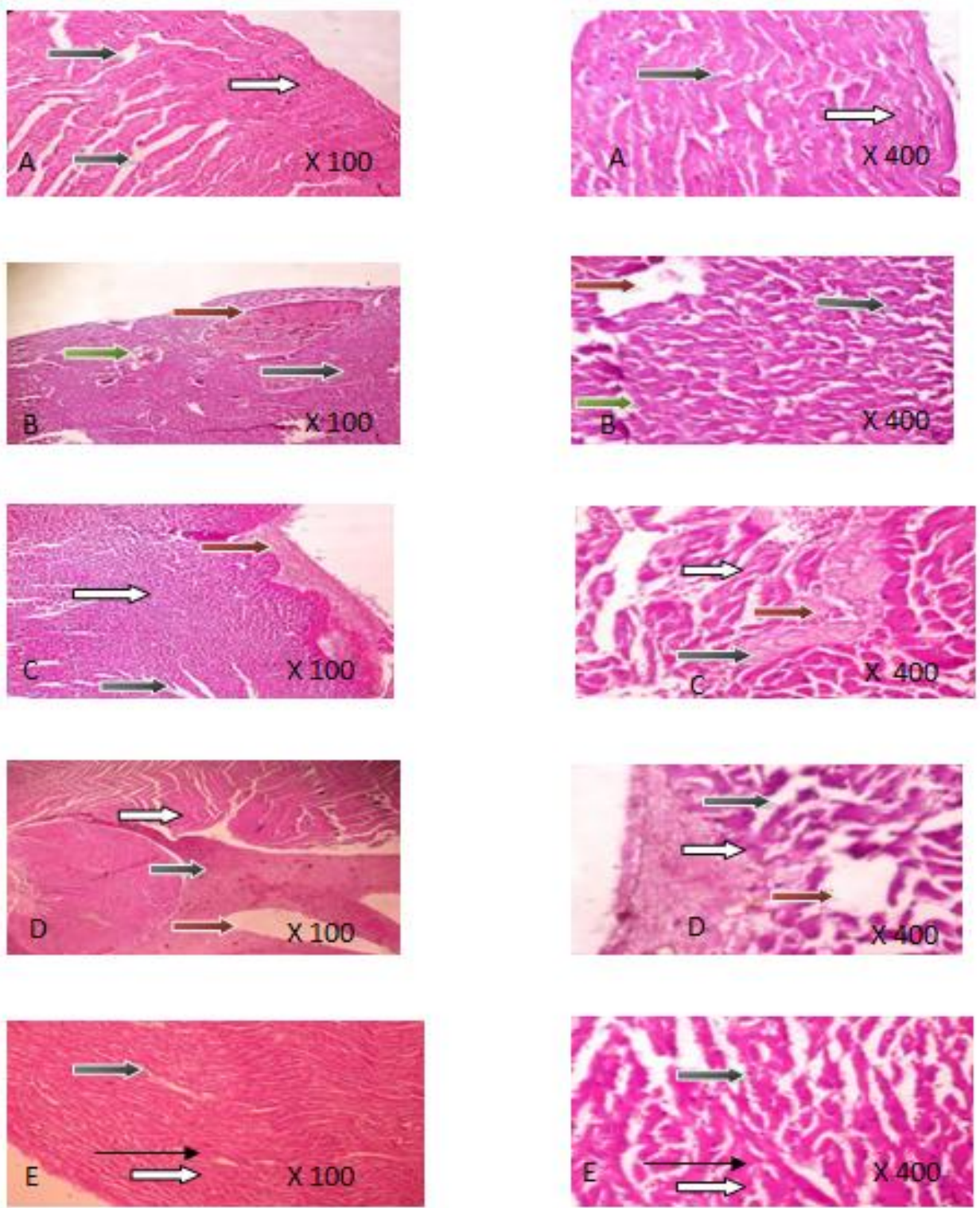

Plate 1. Haematoxylin and eosin staining shows the effect of a methanolic extract of Adansonia digitata on the histological morphology of the rat heart

A: Control (Normal saline); B: DOX- induced untreated; C: DOX + Vit E; D: DOX + 150mg/kg bw ADME; E: DOX $+300 \mathrm{mg} / \mathrm{kg}$ bw $A D M E$

The myocardium of the control group animals had regular architecture, according to histopathology. (Plate 1A) but the heart section of doxorubicin treated pathogenic rats showed remarkable necrosis, edema and infiltration of chronic inflammatory cells with hemorrhage (Plate 1B). However, the photomicrograph of Vitamin $E$ treated group showed normal epicardial layer (white arrow), normal myocardial layer (black arrow) and mild hemorrhage (red arrow). The heart section of DOX $+150 \mathrm{mg} / \mathrm{kg} / \mathrm{wt}$ of the extract has moderate hemorrhage (black arrow), vocal area of mild edema (red arrow) as seen at the pericardial layer while other areas of epicardial layer appears normal (Plate 1D). The photomicrograph of the heart section of DOX + $300 \mathrm{mg} / \mathrm{kg} / \mathrm{wt}$ of the extract has very mild infiltration of inflammatory cells (white arrow) at 
the pericardial layer, normal myocardial layer (black arrow) and no haemorrhage as shown in Plate 1E indicating that the methanolic extract of the plant has significant cardioprotective effect and it also maintained myocardial membrane integrity.

\section{DISCUSSION}

Cardiovascular disorders (CVDs) are a category of conditions that affect the heart and its components. Per the incidence of cardiovascular disorders around the globe, the most significant CVDs are elevated blood pressure, coronary heart attack, myocardial infarction, congenital heart abnormalities, cardiac arrhythmias, heart failure, and stroke [32]. Heart attack kills more individuals worldwide than any other cause. According to Kandlepu et al. [33], in 2012, almost 17.5 million people died of CVDs, representing $31 \%$ of all worldwide deaths. If current trends persist, a projected 23.6 million people would die from cardiovascular diseases by 2030. [34]. While certain current medications, such as organic nitrate, calcium channel antagonist, and blocker, are useful in preventing heart disease, their usage is also restricted due to side effects. Doxorubicin, an anthracyline compound, is a commonly prescribed chemotherapeutic agent for a variety of cancers, including breast cancer, bladder cancer, kaposissacroma, lymphoma, and acute lymphocytic leukemia $[35,36]$. The therapeutic activity of doxorubicin on tumor cells differs from that of its cardiotoxicity. DNA intercalation, which prevents macromolecule synthesis, DNA binding and DNA crosslinking, DNA damage caused by topoisomerase II inhibition, and induction of apoptosis caused by topoisomerase II inhibition are all proposed mechanisms for its anti-malignancy effect $[37,38,39]$. The cause of doxorubicin cardiotoxicity is thought to be elevated oxidative stress, which leads to increased amounts of reactive oxygen species and lipid peroxidation $[40,41,42,39]$. Reduced antioxidant and sulfhydry group amounts [43,44, 42,45], nucleic acid and protein synthesis inhibition [46,47], release of vasoactive amines [48], and altered adren [49], decrease in cardiovascular expression are other mechanisms that has been proposed.

Doxorubicin inflicts toxic harm to cardiomyocyte mitochondria, causing mitochondrial enzymes including NADH dehydrogenase, cytochrome P450 reductase, and xanthine oxidase to produce oxygen free radicals $[50,51]$, by inhibiting endothelial nitric oxide synthase, doxorubicin aids the production of intracellular hydroperoxide [52,53]. [54]. The drug's downregulation of -actin, myosin light and long chains, troponin-I, and desmin proteins has been suggested as a potential trigger of doxorubicin cardiotoxicity. Reduced myofibrillar loss and myocardial contractile function are attributed to lower contractile protein expression $[55,56]$. Downregulation of the sacroplasmic reticular ATPase may result in abnormal myocardial diastolic behavior [55,57]. Doxorubicin can also inactivate intracellular signal-regulated kinase [56]. Commercially available synthetic cardioprotective medicines are harmful to certain communities and remain out of control. Some medicinal plants have been studied for their cardioprotective properties which showed o be both powerful and affordable [58, 7, 59,60]. As a consequence, several scientists are interested in green products that have cardioprotective and antioxidative effects. Adansonia digitata has been used widely as a supplement for Western medicine in different therapies since prehistoric times. [61]. Through reducing free radicals that trigger these chronic illnesses, baobab leaves and fruits may help to reduce oxidative stress-related diseases like cancer, aging, asthma, and cardiovascular disease. [62,63]. The active constituents of polyphenols such as proanthocyanidins and flavonoids, saponins, and glycosides in the plant's leaf extract display cardioprotective effects in the current analysis, which can be due to their active constituents of polyphenols such as proanthocyanidins and flavonoids, saponins, and glycosides $[64,65,66]$. It has been documented that Adansonia digitata leaf extract is high in Vitamin $\mathrm{C}$, which are phenolic compounds with hydroxyl groups in their form and have antioxidant activity [67, 68,69]. Polyphenols may also affect the function of main enzymes including glycosidase. A series of essential biological processes require glycosides (such as digestion, glycoprotein biosynthesis, and glucoconjugate lysosomal catabolism) that are linked to metabolic disorders and diseases such as diabetes, obesity, glycosphingolipids, lysosomal storage disease, HIV infections, and tumors [70]. Glycosidase inhibition will be an innovative approach to treating the above complications. In the present research, the increased redox state of doxorubicin induced rats treated with Adansonia digitata leaf extract could have led to these compounds [71]. Further, methanol extract from the plant was shown as an inhibitior of nitric oxide concentration to reducing inflammatory plasma markers such as IL-6 and 
TNF-, which could aid in the suppression of peroxyl radicals in diseases caused by free radicals [71]. In the present research, there was a significant increase in levels of cardiac marker enzymes (CK-MB, LDH, AST) in the heart tissue during Doxorubicin administration which has caused mitochondrial enzymes to produce oxygen free radicals [51], as observed in Group II. when compared to the control rats (Group 1), whereas methanolic leaf extract (Group IV and Group V) and Vitamin E treatment (Group III) significantly decreased the elevated activities of cardiac CK, LDH, and AST, as shown in Fig. 1 as observed also by (Swamy et al 2011) [17]

Catalase is an enzyme that catalyzes the conversion of hydrogen peroxide to water and molecular oxygen, and as a result, protects the body from oxidative abuses (Ebaid et al. 2019), Superoxide dismutase (SOD) is an enzyme that scavenge superoxide ion to either molecular oxygen or hydrogen peroxide while NO acts an important cellular signaling molecule and modulates vascular tone So the decrease of NO,CAT,SOD in the heart tissue were significantly reduced $(P<0.05)$, but these reductions were significantly reversed in Groups III, IV, and V rats (Table 2 and Fig. 2). Malondialdehyde is a lipid peroxidation product that causes cellular damage by reacting with lipids, thereby causing peroxidation and release of products including hydrogen peroxide, Pretreatment with Adansonia digitata methanolic extract and Vitamin $E$ significantly reduced the elevated level of malondialdehyde in Group IV, Group V and Group III respectively compared to the untreated Group I which was corresponding to the result of (Ogunleye et al. 2020; Ebaid et al. 2019)

\section{CONCLUSION}

Treatment with a methanolic extract of Adansonia digitata alleviated the problems induced by oxidative stress as shown by improved oxidative stress biomarkers. Finally, the current study found that rats pretreated with a methanolic leaf extract of Adansonia digitata were shielded from doxorubicin-induced myocardial injury.

\section{ACKNOWLEDGEMENT}

Big thanks goes the former Head of Biochemistry Department Dr. Olaniyan, for his careful supervision of the project, also we in the same vein appreciate Davejosh Global resource laboratory, Ogbomoso. Nigeria for the assistance during the project lab analysis.

\section{COMPETING INTERESTS}

Authors have declared that no competing interests exist.

\section{REFERENCES}

1. Brayfield A. Doxorubicin. Martindale: The Complete Drug Reference. Pharmaceutical Press; 2013.

2. Chaterjee Kamu, Jianqing Zhang, Norman Honbo and JuelKarliner. Doxorubicin Cardiomyopathy. Cardiology. 2010;115(2):155-162.

3. Felker GM, Thomphsson RE, Hare JM, Hruban RH, Clemetson DE, Howard DL, Baughman KL, Kasper EK. Underlying causes and long term survival in patients with initially unexplained cardiomyopathy. New. Engl. J. Med. 2000;342:1077-1084.

4. Jensen BV, Skovsgaard T, Nielsen L. Functional monitoring of anthracylinecardiotoxicity; a prospective, blinded, long term observational study of outcome in 120 patients. Ann. Oncol. 2002;13:699-709.

5. Althaf Hussain Shaik $S N$, Rasool A, Vikram Kumar Reddy M, Abdulkareem G. Saaji Krushna K, Lakshmi Devi. Cardioprotective effect of HPLC standardized ethanolic extract of Terminaliapallida fruits against isoproterenol-induced myocardial infarction in albino rats. Journal of Ethnopharmacology. 2012;14:23-40.

6. Mukesh Nandare, Shreesh Kumar Ojha, Santosh Kumari, Tapas Chandra Nag, Ray Mehra, Rajiv Narang, Dharamvir Singh Arya. Cardioprotective effect of root extract of Picrorhizakurroa (Royle Ex Benth) against isoproterenol - induced cardiotoxicity in rats. Indian Journal of Experimental Biology. 2013;51:694-701

7. Priya Saxena, Dharamveer Panjwomi. Cardioprotective potential of hydroalcoholic fruit extract of Ananascosmosus against isoproterenol-induced myocardial infarction in Winstar Albino rats. Journal of Acute Disease. 2014;228-234.

8. Salim AS, Simons AJ, Orwa C, Chege B, Mutua A. Adansonia digitata. Agroforestree database a tree species reference and selection guide. International Centre for Research in Agroforestry, Nairobi; 2012. 
9. Yazzie D, Vanderjagt DJ, Pastuszyn A, Okolo A, Glew RH. The amino acid and mineral content of Baobab (Adansoniadigitata L.) leaves. Journal of Food Compost Anal. 1994;7:189193.

10. Sidibe M, Williams JT. Baobab (Adansonia digitata). International Centre for underutilized Crops, Southampton; 2002.

11. DeCaluwe E, Halamova K, Van Damme P. Baobab (Adansonia digitata L.) a review of traditional uses, phytochemistry and pharmacology. RH Juhani JE Simon CT Ho (Eds). African natural plant productse: new discoveries and challenges in chemistry and quality. American Chemical Society, Washington D.C. 2009;51-84.

12. Chadare FJ, Linnermann AR, Hounhouigan JD, Nout MJ, Van Boekel MA. Baobab food products'. A review on their composition and nutritional value. Crit Rev. Food Sci. Nutr. 2009;49:254-274.

13. Chadare FJ. Baobab (Adansonia digitata L.) foods from Benin composition, processing and quality, Wageningen University,Wageningen; 2010.

14. Diop PA, Franck D, Grimm P, Hasselimann C. High performance liquid chromatographic determination of Vitamin $C$ in fresh fruits from West Africa. J. Food Compost. Ana. 1988;1:265-269.

15. Eromosele IC, Eromosele CD, Kuzhkuzha DM. Evaluation of mineral elements and ascorbic acid contents in fruits of some wild plants. Plant Foods Hum. Nutr. 1991;41:151-154.

16. Odetokun SM. The nutritive value of baobab fruit (Adansonia digitata). Rivistaltalianadelle Sostance Grasse. 1996;73:337-371.

17. Mona AMG, Amal IH, Mand GM, Mohsen SA. Protective effect of Adansonia digitata against isoproterenol-induced myocardial injury in rats. Animal Biotechnology. 2016;27(2):84-95.

18. Watt JM, Breyer-Brandwijk MG. The medicinal and poisnous plants of Southern and Eastern Africa (2 ${ }^{\text {nd }}$ ed.), E \&S. Livingstone Ltd, Edinburgh and London; 1962.

19. Van Wyk BE, Gericke N. Peoples plants: a guide to useful plants of Southern Africa $\left(1^{\text {st }}\right.$ ed.)Briza Publications, Pretoria; 2000.

20. Brendler T, Gruenwald J, Jaenicke C. Herbal remedies. (CD-ROM).Medpharm $\mathrm{GmbH}$ Scientific Publishers, Stuttgart; 2003.
21. Tapsoba $H$, Deschamps JP. Use of medicinal plants for the treatment of oral diseases in Burkina Faso. J. Ethnopharmacology. 2006;104:68-78.

22. Wickens GE, Lowe $P$. The baobabs; pachycauls of Africa, Madagascar and Australia, Springer, Berlin; 2008.

23. Nguta JM, Mbarca JM, Gakuya DM, Gathumbi PK, Kama SG. Antimalarial herbal remedies of Msambweni. Kenya J. Ethropharmacology. 2010;128;424-432.

24. Wurzburg U, Hennrich N, Lang H, Prellwitz W, Neumeier D, Kendel M. Determination of creatinine kinase - MB in serum using inhibition antibodies. Klin. Wochenschr. 1976;54(8):357-360.

25. Szasz G, Gerhard W, Gruber W. Creatinine kinase in serum; 5 . Effect of trial on isoenzymeactivity during storage at various temperatures. Clin.Chem. 1978;24(9):1557-1563.

26. Rietman S, Frankel S. A colorimetric method for the determination of serum GOT and GPT. American Journal of Clinical Pathology. 1957;28:56-63.

27. Ochei J, Kolhatkar A. Medical Laboratory Science : theory and practie. Tata Meegram - Hill Publishing Company Limited, New Delhi; 2005.

28. Misra HP, Fridovich I. The role of superoxide anion in the autoxidation of epinephrine and a simple assay for superoxide dismutase. J. Biol. Chem. 1972;247(10):3170-3175.

29. Aebi H. Catalase In; Methods of enzymatic analysis. Ed. By Hu Bergmeyer, Chemic Academic Press Inc Verlog. 1974;2:673685.

30. Marcocci L, Maguire JJ, Droy-Lefany MT, Packer L. The nitric oxide scavenging properties of Ginkobloba extract EGb761. Biochem. Biophys. Res. Commun. 1994;201:748-755.

31. Varshey Rand Kale RK. Effect of calmodulin antagonist on radiation induced lipid peroxidation in microsomes. Int. J. Rad. Biol. 1990;58:733-743.

32. Mackays J, Mensah G. The atlas of heart diseases and stroke. World Health Organization. Geneva; 2001.

33. Konlepu $H$, Sushama M, Durvasu JB. A comprehensive review of cardioprotective medicinal plants. International Journal of Invention in Pharmaceutical Science. 2014;2(4):793-799.

34. Nazish J, Khalil-UR-Shoukat A. Cardioprotective and antilipidemic potential 
of Cyprus rotundas in chemically induced cardiotoxicity. Int. J. Agric. Biol. 2012;14:989-992.

35. Weiss RB. The anthracycline will ever find a better doxorubicin. Semin. Oncol. 1992;19:670-686.

36. Jordan MA. Anticancer agents. Curr. Med. Chem 2002;2:1-7.

37. Gerwitz DA. A critical evaluation of the mechanisms of action proposed for the antitumour effects of the anthracycline antibiotics. Adriamycin and doxorubicin. Biochem Pharmacol. 1999;57:727-741.

38. Munnoti G, Menna P, Salvatorelli E, Cairo G, Ganni L. Anthracyclines; molecular advances and pharmacologic developments in antitumour activity and cardiotoxicity. Pharmacol Rev. 2004;56:185-229.

39. Takemura G, Fujiwara H. Doxorubicin induced cardiomyopathy from the cardiotoxic mechanism to management. Prog. Cardiovascular Disease. 2007;49:330-352.

40. Kalyanaraman B, Perez-Royes E, Marson RP. Spin-trapping and direct electron spin resonance investigation of the redox metabolism of quinone anticancer drugs. Biochem. Biophysics Acta 1980;630:119130.

41. Doroshow JH. Effect of anthracycline antibiotics on oxygen radical formation in rat heart. Cancer Res. 1983;43:460-472.

42. Singal PK, Segstro RJ, Singh RP, Kutryk MJ. Changes in lysosomal morphology and enzyme activities during one development of Adriamycin-induced cardiomyopathy. Can. J. Cardiol. 1985;1: 139-147.

43. Doroshow JH, Locker GY, Baldinger J, Myers CE. The effect of doxorubicin on hepatic and cardiac glutathione. Res. Commun. Chem. Pathol Pharmacol. 1979;26:285-295.

44. Olson RD, Mac Donald JS, Van Boxtel CJ, Boerth RC, Harbison RD, Slonim AE, Freeman RW, Oates JA. Regulatory role of glutathione and soluble sulfhydryl groups in the toxicity of Adriamycin. J. Exp. Therm. 1980;215:450-454.

45. Odom AL, Hatiw CA, Stanley JS, Benson AM. Biochemical determinants of Adriamycin toxicity in mouse, liver, heart and intestine. Biochem. Pharmacol. 1992;43:831-836.

46. Arena E, D' Alessandro N, Dusonchet L, Goraci M, Rausa L, Sanguedolce R. Repair kinetics of DNA, RNA and proteins in the tissues of mice treated with doxorubicin. Arzneimittel for Schung. 1979;29: 901-902.

47. Monti E, Prosper E, Supino R, Bottiroli G. Free radical-dependent DNA lesion are involved in the delayed cardiotoxicity induced by Adriamycin in the rat. Anticancer Res. 1995;15:1933-197.

48. Bristow MR, Sageonar WS, Scott $\mathrm{RH}$, Billingham ME, Bowden RE, Kernoff RS, Snidow GH, Daniels JR. Acute and chronic cardiovascular effect of doxorubicin in the dog: the cardiovascular pharmacology of drug-induced histamine release. J. CardiovascPharmocol. 1980;2:487-515.

49. Tong J, Gangnly PK, Singal PK. Myocardial adrenergic changes at two stages of heart failure due to Adriamycin treatment in rats. Am. J. Physiol Heart CircPhysiol. 1991;260:909-916.

50. Bachur NR, Gordon SL, Gee MV. NADPH cytochrome $\mathrm{P}-450$ reductase activation of quinine anticancer agents to free radicals. Proc. Natl. Acad Sci. USA. 1979;76:954957.

51. Davies KJ, Doroshow JH. Redox cycling of anthracyclines by cardiac mithochondiria I. Anthracydine radical formation by $\mathrm{NADH}$ dehydrogenase. J. Biol. Chem. 1986;261:3060-3067.

52. Vasquez-Vivar J, Montasek $\mathrm{P}$, Hogg N, Masters BS, Pritchard KA Jr, Kalyanaraman B. Endothelial nitric oxide synthase - dependent superoxide generation from Adriamycin. Biochemistry. 1997;36:11293-11297.

53. Kalivendi SV, Kotamraju S, Zhao $H$, Joseph J, Kalyanaraman B. Doxorubicininduced apoptosis is associated with increased transcription of endothelial nitric - oxide synthase.Effect of antiapoptotic antioxidants and calcium. J. Biol. Chem. 2001;276:47266 - 47276.

54. Kotamraju S, Konorev EA, Joseph J, Kalyanaraman B. Doxorubicin induced apoptosis in endothelial cells and cardiomyocytes is ameloriated by nitrone spin traps and ebselen. Role of reactive oxygen and nitrogen species. J. Biol. Chem. 2000;257:33585-33592.

55. Kim Y, Ma A, Kitta K, Fitch SN, Ikeda T, Ihara Y, Simon AR, Evans T, Suzuki YJ. Anthracycline induced suppression of GATA-4 transcription factor: implication in the regulation of cardiacmyocyte apoptosis. Mol Pharmacol. 2003;63:368377. 
56. Lou H, Danelisen I, Singal PK. Involvement of mitogen-activated protein kinases in adriamycin-induced cardiomyopathy. Am J. Physiol Heart Circ Physiol. 2005;288:H1925-H1930.

57. Aries $P$, Paradis $P$, Lefevre $C$, Schwartz RJ, Nemer M. Essential role of GATA-4 in cell survival and drug-induced cardiotoxicity. Proc. Natl Acad Sci. USA. 2004;101:6975-6980.

58. Karthik Mohan, Karthika. Cardioprotective effect of the methanolic extract of boiled peanut (Arachis hypogeal) on isoproterenol induced myocardial infarction in albino rats. American Journal of Phytomedicine and Clinical Therapeutic. 2013;1(4):408415.

59. Karunakar Hedge nnd DhruvpatelKeerthi. Evaluation of cardioprotectiveactivity of aqeous extract of Garcinaindicalinn fruit rind. Asian Journal of Pharmaceutical and Clinical Research. 2015;8(2):107-112.

60. Nagaraju B, Vidhyadhara S, Aruna Kumarch, Vikas S, Suryanarayanaraju. Evaluation of cardioprotective activity of ethanolic extract of dried leavesof Cinnamomumtamala in rats. International Journal of Biomedical and Advanced Research. 2016;7(4):181-186.

61. Namratha $V$, Baobaba SP. A review about the tree of life. International Journal of Advanced Herbal Science and Technology. 2015;1:20-26.

62. Blomhoff R, Carlsen M, Halvorsen B, Holte K, Bohn S, Dragland S, Sampson L, Willey C, Seroo $H$, Umezomo $Y$, Sanada C, Barikmo I, Berhe N, Willet W, Phillips K, Jacob D. The total antioxidant content of more than 3,100 foods, beverages, spices, herbs and supplements used Worldwide. Nut J. 2010;9:3.

63. Kaur C, Kapoor HC. Antioxidant in fruits and vegetables. Int. J. Food Sci. Technol. 2001;36:703-725.

64. McDougall GJ, Shipro F, Dobson P, Smith $\mathrm{P}$, Blake A, Stewart D. Different polyphenolic compounds of some fruit inhibit $\alpha$-amylase and $\alpha$-glucosidase. J. Agric. Food Chem. 2005;53:2760-2766.

65. Fernades de Olivera AM, Sousa Pinhero L, Souto Pereira CK, NeresMatias W, Albuquerque Gomes R, Souza Chares O, Vanderlei de Souza Mde F, Nobrega de Almeida R, Simoes de Assis T. Total phenolic content and antioxidant capacity of baobab products. Food Chem. 2012;102:1352-1356.

66. Sokeng AJT, Sobolev AP, Kim YJ, Retta N, Dessie G, Kim HS. A methanol extract of Adansonia digitata leaves inhibits proinflammatory NOS possibly via the inhibition of NF-KB activation. Biomol Ther. 2013;21:146-152.

67. Vertuani S, Braccioli E, Buzzon V, Manfredini S. Antioxidant capacity of Adansonia digitata fruit pulp and leaves. Acta Phythotherapeutic. 2002;81:2-7.

68. Besco E, Braccioli E, Vertuani S, Zios P, Brazzo F, Bruni R, Sacchetti G, Manfredini $\mathrm{S}$. The use of photochemiluminescencefor the measurement of the integral antioxidant capacity of baobab products. Food Chem. 2007;102:1352- 1356.

69. Brady $O$. The characterisation and bioactivity determination of Adansonia digitata fruit psulp for commercial product development. Thesis of Bachelor of Science in Nutraceutical for Health and Nutrition. Dublin. Institute of Technology, Cathal Brugha Street. 2011;117.

70. Kim JH, Ryn YB, Kang NS, Lee BW, Heo JS, Jeong IY, Park KH. Glycosidase inhibitory flavonoids from Sophoraflavescens. Biol. Pharm. Bull. 2006;29:302-305.

71. Ayele Y, Kim JA, Parl Y. A methanol extract of Adansonia digitata L. leaves inhibits inflammatory NOS possibly via the inhibition of NF-KB activation. Biomolecules and Therapeutics. 2013;21 (2):146-152.

(c) 2021 Olayemi et al.; This is an Open Access article distributed under the terms of the Creative Commons Attribution License (http://creativecommons.org/licenses/by/4.0), which permits unrestricted use, distribution, and reproduction in any medium, provided the original work is properly cited.

Peer-review history:

The peer review history for this paper can be accessed here: https://www.sdiarticle4.com/review-history/69342 